\title{
STATE AND LOCAL TAXATION OF THE UNITED STATES AND ITS CONTRACTORS
}

\author{
Richard E. Speidel*
}

\section{Mr. Martin:}

Good morning ladies and gentlemen. Welcome to the second session of our annual institute on Government Contracts. I am your moderator. The topic for discussion this morning is "State and Local Taxation of the United States and its Contractors." This is usually considered to be an esoteric and rather dry subject. Nothing could be farther from the truth. When discussing what Mr. Justice Frankfurter has called the "interpenetrating" problems of federalism, ${ }^{1}$ we are concerned with one of the most controversial and complex domestic issues of our time. This will be clearly revealed when the discrimination aspects of this problem are discussed later on.

Our panel is well qualified and has been selected with an eye to sharpening your awareness of the various interests involved. All of these gentlemen, including our reporter, are attorneys. On my far right is Mr. Charles, who represents a large number of important government contractors. On my far left is Mr. Sampson, who is now serving as legal adviser to the Department of Revenue of one of our largest states. On my immediate right is Mr. Fish, assistant general counsel in a Department of Defense contracting agency. On my immediate left is Mr. Potter, Professor of Law at Benzoin University. Our reporter is Mr. Roberts, who will both transcribe these proceedings and prepare some separate notes after the session is over. We want these discussions to be informal and everybody to have a chance to speak. Mr. Charles, why don't you get things going.

\section{Mr. Charles:}

Thank you Mr. Martin. For many years I have represented a number of government contractors. They have provided a wide variety of supplies and services, from soap to weapons systems to just plain basic research, under every conceivable type of contractual arrangement. They have used whenever possible the government's generous programs of assistance, such as progress and advance payments and government-furnished property. Most of my clients do business in more than one state. They have been taxed by almost every state and local government and have dealt with a wide range of state tax officials and federal contract administrators. Their composite experience is revealing and, frankly, their primary concern is profit. Anyone who says otherwise is not being realistic. It is perfectly clear to me that to these

* B.A. 1954, Denison University; LL.B. I957, University of Cincinnati; LL.M. I958, Northwestern University. Member of the Ohio bar. Associate Professor of Law, University of Virginia. Formerly instructor in Government Contracts, The Judge Advocate General's School. Contributor to legal periodicals.

${ }^{1}$ City of Detroit v. Murray Corp., 355 U.S. 489, 495 (1958). 
contractors, state and local taxes are regarded as a potential threat to the profit margin.

Even so, most contractors still cannot see that there is an insoluble problem here. "What's all the fuss about?" is the most frequent question I get. To them, state and local taxes are legitimate costs of performing government or any other contracts. If reasonable and otherwise allocable to performance, why shouldn't they be reimbursed by the government just like any other direct or indirect cost? If labor or material costs go up the increase is included in the contract price. Why not new or increased state and local taxes?

Mr. Fish:

Well, while I'm not so sure that I agree with this approach, the Department of Defense does not insist that its private contractors bear the full burden of valid, allocable state and local business taxes. A careful study of the standard tax clauses and contract cost principles confirms this. ${ }^{2}$ Rather than consciously placing the risk of all state taxation on the contractor, the government has agreed to reimburse the contractor for taxes from which he is not exempt and tried to minimize the cost burden to itself by close pricing in negotiated contracts and by relying on price competition when the contract is awarded by formal advertising. This gets rid of quite a few "marginal" costs, such as income taxes, and other amounts included for contingencies. And where the contract is awarded by formal advertising the tax risk of both parties is solidified at the time the bids are opened. There is no contractual provision for price escalation, either up or down, if the tax picture subsequently changes. ${ }^{3}$ Taxes are really not treated any differently than other performance costs.

Mr. Martin:

This seems quite sensible. Why did you express doubt about the approach. Wouldn't any other approach be disastrous?

\section{Mr. Fish:}

What do you mean, disastrous? If you could see the drain on our appropriations and actually participate in the time-consuming negotiations, administrative headaches, and tax litigation, it would become perfectly clear what is really involved here. Government contracts are awarded to implement carefully planned long and short range programs, and private business cooperation is essential for success. These

${ }^{3}$ Armed Services Procurement Regulation (ASPR), $\S$ II-40I.I (Aug. I96I), $\S$ II-40I.2(b) (July 1960), 32 C.F.R. \$Ir.40I (I963) (tax clauses for fixed-price contracts); ASPR $\$$ 15-205.4T, 32 C.F.R. $\$ 15.205 .4 \mathrm{I}$ (1963) (tax cost principles in cost reimbursement contracts).

${ }^{3}$ ASPR $\S$ II-40I.I (Aug. I96I), 32 C.F.R. $\$$ II.40I ( 1963 ). In negotiated contracts over $\$ 10,000$ in amount where the contracting officer is not satisfied that the contract price excludes contingencies for state and local taxes, limited price escalation is available. ASPR $\S$ II-40r-2(b) (July I960), 32 C.F.R. \$II.40I (1963). For a discussion of the standard tax clauses and cost principles, see KarI E. WOLF, State and Local Taxatton 34-4I (I962) (Government Contracts Monograph No. 5, The George Washington University). 
programs serve the public interest and many involve essential aspects of national defense. To say that the accomplishment of these vital federal functions is not substantially burdened, both economically and administratively, by state and local taxation is just plain nonsense. And the nonsense is compounded by the fact that we are subsidizing state and local governments out of funds appropriated for federal contract performance. The contractor is a mere conduit through which the handout is made. It just burns me up that all of the taxpayers in the United States contribute a subsidy given to the few states which fortuitously have citizens who are also government contractors. You would think that just having all that business in the state would be enough benefit without adding taxes to it. No one ever asks whether the state actually needs the tax revenue. Everyone just assumes that they do. It seems to me that the "disaster" in this problem is the actual and potential economic and administrative burden imposed on legitimate federal functions." Any such burdens placed on the contracting process are burdens on national defense.

Mr. Charles:

Well, don't kid yourself into thinking that you can obtain "disaster relief" by putting the risk on the government contractor. If my clients were compelled to absorb the entire cost of state and local taxation most would be unwilling or unable to do business with the United States. The best patriotic motives fade before the prospect of losing money. Many contractors would be priced right out of the market. Others would be placed at a competitive disadvantage in dealing with contractors from states with lower taxes. The overall result of this could be a smaller base of capable contractors, adverse effects on the small business, and higher contract prices in general. And if the tax burden were consciously placed on the contractor, those that could still participate would increase their costs. Neither formal advertising nor good price negotiation could effectively reduce prices or eliminate all the contingencies. It would be a sorry day for government contracting.

\section{Professor Potter:}

You have made an excellent point. Obvious damage is done to the private contractor's profit expectation unless he can pad his price for contingencies. But the intriguing suggestion is that the "public interest" here has a dual aspect which must be considered. It seems to me that you are arguing that a conscious risk imposition on private contractors to reduce the burdens that state taxation places on the contracting process might impair the public interest in a broad base of capable, willing and able contractors. It will ultimately damage the mobilization base, in other words. Since both economy and a broad contractor base are essential to efficient defense contracting, this particular risk allocation might not work.

Mr. Charles:

Perhaps, but I've never been too clear what is and what is not in the public

' For an elaboration of this viewpoint, see Van Cleve, States' Rights and Federal Solvency, 1959 Wis. L. REv. 190, 207-212. 
interest.5 If the private contractor's interest in a fair profit is roughly synonymous with the government's interest in a broad mobilization base, then we are in agreement.

\section{Mr. Martin:}

Accepting what has been said at face value, doesn't this shoot a big hole in the notion that the economic and administrative burden of state and local taxation of contractors need not be assumed by the United States. In theory the government could refuse to reimburse the contractor's tax costs but in practice it cannot. While the government may have almost unlimited power to dictate the terms of its bargain with private industry, it cannot compel the contractor to do business. It must induce him with fair profit. Because of this I would hope that throughout the rest of this discussion we can recognize that one of the realities of government contracting is that the practical operation of most state and local taxation ostensibly directed at the private contractor must by necessity fall on the United States.

Mr. Fish:

I will concede that a blanket risk imposition technique may be unrealistic. But the government's burdens can be reduced by other methods which at the same time preserve the contractor's profit margin. Congress, for example, could by legislation immunize all government contractors from state and local taxation. Private business concerns would receive the same tax immunity possessed by the United States, its agents and instrumentalities. ${ }^{6}$ And if Congress failed to act, the executive agencies can confer quite a bit of immunity by carefully drafted contract clauses. One good illustration is the practice of making the contractor a government "purchasing agent" to avoid state sales and use taxes." Either approach would

"Cf. Miller, The Public Interest Undefined, ro J. Public L. $x 84$ (I96r).

${ }^{\circ}$ In Carson v. Roane-Anderson Co., 342 U.S. 232 (I952), a private contractor of the Atomic Energy Commission was held exempt from state sales and use taxes by virtue of an act of Congress, 60 Stat. 765 (1946) which provided that "the activities . . . of the Commission, are hereby expressly exempted from taxation in any manner or form by any state. . . ." The Court stated:

The constitutional power of Congress to protect any of its agencies from state taxation . . . has long been recognized as applying to those with whom it has made authorized contracts. Certainly the policy behind the power of Congress to create tax immunities does not turn on the nature of the agency doing the work of the government. The power stems from the power to preserve and protect functions validly authorized-the power to make all laws necessary and proper for carrying into execution the powers vested in the Congress. U.S. ConsT. art. I, $\S 8, \mathrm{cl}$. I8.

Id. at 233. While the Court concluded that the word "activities" was broad enough to include private contractors, Congress subsequently repealed the exemption. 67 Stat. 575 (I953).

7 The typical government contractor is not an agent of the United States for purposes of tax avoidance, although "in a certain loose way it might be called an instrumentality of the United States." United States v. Township of Muskegon, 355 U.S. 466, 486 (I958). See Alabama v. King \& Boozer, 3 I 4 U.S. I (1941). Tax immunity can be obtained, however, by altering the normal contractual relationship to specifically designate the contractor a "purchasing agent" of the United States. Kern-Limerick v. Scurlock, 347 U.S. I Io (I954); United States v. Livingston, I79 F. Supp. 9 (E.D.S.C. I959), affd, 364 U.S. 28I (I960); United States v. Boyd, 363 S.W.2d I93 (Tenn. 1962). See WoLF, op. cit. supra note 3 , at 26 . Similarly, the impact of state ad valorem property taxes may be reduced by causing "title" to facilities, equipment, inventory and work in process in the possession of a private contractor to vest in the United States during contract performance. See Whelan, Government Contract Privileges: $A$ Fertile Ground for State Taxation, 44 VA. L. REV. I099, II07 (I958). 
protect both aspects of the public interest we have been discussing without affecting the profit inducement offered to private contractors. The state would have no power to tax the business activities of government contractors.

Mr. Martin:

I think we had better let Mr. Sampson speak before he has a stroke.

\section{Mr. Sampson:}

Thank you. I've been listening to all this garble for some time now and its about time for me to put my two cents in. You all have ignored the legitimate state interests involved in this problem. There are a whole set of economic and political realities that must be considered. In my state, we need more revenue to support the many governmental services provided all our citizens, including government contractors. It is no fortuity that a large number of contractors have located with us. They were attracted by a solid history of economic growth and good government. We want them and we seek to attract them by offering more and better services and protection. But we can't play favorites. Good tax policy requires that all business within the state share the cost of governmental services provided to all. Government contracts are not usually performed in federal plants on federal enclaves. They are performed by private business in private facilities and require the same governmental services as anyone else. What justification exists for treating them differently? There is none.

It is my humble opinion that a blanket tax immunity conferred by any method upon the government contractor would be disastrous to the state revenue system and leave its imprint on much more. It's bad enough to have a wide variety of federally-owned tax exempt property on the books. This creates hardship. But additional immunity would compound this hardship by removing a huge chunk of potential revenue from the states. Unless overall services were drastically reduced the entire tax burden would be cast on private business not fortunate enough to have government contracts. This inequity could not be tolerated and the state would be forced to terminate its services and protection to the government contractor. How much do you think it would cost the federal government to take up the slack? Do you think it would be any less than the taxes now paid? Do you think the services would be anywhere near as effective? I doubt it seriously. ${ }^{8}$

\section{Mr. Martin:}

I hesitate to interject, but isn't this just another illustration of how difficult it is to identify and accommodate legitimate competing interests in our federal system.

\footnotetext{
${ }^{8}$ For an elaboration of this viewpoint, see Pierce, Tax Immunity Should Not Mean Tax Inequity, 1959 WIs. L. REv. 173. See also, Stephens \& Schmandt, Revenue Patterns of Local Governments, I5 NAT'L TAX J. 432 (I962) (cost of local government has quadrupled since World War II); Myers \& Stout, The Role of the States and Local Governments in National Fiscal Policy, ro NAT'L 'TAx J. 17x, 174 (I957) (criticizes excessive use of tax exemptions as distorting state and local tax structurc and creating inequitable tax burdens).
} 
From this discussion it seems clear that either imposing a blanket risk imposition or conferring a blanket tax immunity on the contractor would be unworkable. A "crude rule of thumb" would ignore legitimate state and private interests. On the other hand, giving the states an unlimited power to tax also has drawbacks. In view of the potential burdens on the federal contracting process, how can we be sure that limited or total immunity actually creates hardships? By what techniques can the obvious state economic benefits of having government business be balanced against the supposed hardship created by an extension of sovereign tax immunity to the private contractor. And what about the local government with no real revenue needs but with a large amount of potential tax subjects due to a concentration of government contracts?

\section{Professor Potter:}

What about Congress and the "payments in lieu of taxes" approach. As I understand it, in exchange for the state's refraining from taxing certain described subjects the federal government would agree to make direct payments to the state and local governments in lieu of taxes in cases of demonstrable hardship. If, for example, a local government would refrain from taxing a private contractor's "possessory" interest in government owned property, the United States would make a payment to the locality upon proof of hardship or damage to its revenue system caused by a concentration of tax-exempt property or interests. The state would bear the burden of demonstrating a real need or hardship created because of sovereign immunity. This justification would be made to a specially created government agency. Payments would be made from special appropriations to implement the program. This seems realistic to me since all of the competing interests, state, federal, and private, would receive protection commensurate with actual needs in particular cases.

\section{Mr. Fish:}

The idea seems sensible, but the last time it was tried none of the executive agencies could agree what should be included or excluded from the state tax power. The bill died in Congress. ${ }^{?}$

\section{Mr. Martin:}

Well, I guess we shouldn't bog down on a plan which seems sensible but which Congress is either unable or unwilling to enact. A whole host of questions are presented by a "payments in lieu of taxes" plan. What would be the impact on other federal grants-in-aid to the states? Would a state voluntarily consent to this program

\footnotetext{
'See, e.g., S. 9ro, 86th Cong., 2d Sess. (I960), which passed the Senate but died in the House. See also, A Study Commitee Report on Payments in Lieu of Taxes and Shared Revenues to Prestdent's Commission on Intergovernamental Relations (I955); Van Cleve, supra note 4, at 2I5-22. An executive agency cannot make payments in lieu of taxes without express congressional authorization. Sedgwick County v. United States, I23 Ct. Cl. 304 (r952). Congress, however, has authorized payments in lieu of taxes in two specific instances: 68 Stat. 952 (I954), 42 U.S.C. \$2208 (1958) (Atomic Energy Commission); 40 U.S.C. $\$ 5521-24$ (1958) (Reconstruction Finance Corporation, where property transferred to other agencies).
} 
if the burden of proving hardship were placed upon it? And does the creation of another federal agency really change the basic political and economic questions? Sure, the federal contracting agencies will be relieved of some tax burdens, the contractor will still have a chance to earn a fair profit, and the state will be compensated in cases of real hardship. But the money is a federal subsidy and comes from appropriations. Is this wise? Is there justification here for an increase of "positive" government? ${ }^{10}$ (silence) I take it by your silence that these questions give you trouble too.

\section{Professor Potter:}

It seems to me that this is just another area of federalism where Congress is either unable or unwilling to act. There are real, pressing conflicts and controversies which require legislative solution. Yet there is silence from the "Hill." Surely the mere fact of complex and competing state and federal interests should not produce legislative paralysis.

\section{Mr. Sampson:}

Are we to regard that as a question or a pronouncement, professor?

\section{Mr. Charles:}

I have a question, if you don't mind. The tone of this discussion suggests that my client, the government contractor, is just a hapless pawn in a complex and swirling sea of federalism. On the one side we are confronted by the omnipresent state tax assessor and on the other by the majesty of the federal government and its insidious "boiler-plate" clauses. I suppose my client should not complain too much if he is compensated for legitimate tax costs. But he is in the middle and is forced to deal with both sides. For example, since he is contractually responsible for including all legitimate tax costs in his contract price, the responsibility for determining legality is often his. In addition, a great deal of time and effort is involved in seeking exemption certificates from state tax officials. And if a questionable tax is in fact levied, the contractor may be required to pay it under protest and obtain a judicial determination of validity before he can obtain reimbursement from the United States. The threat of litigation is constant, varying in intensity and complexity with the state in which the contract is performed. In view of this, my client would like to know exactly where he stands and this requires that the broader questions be resolved, i.e., just how far can the states go in taxing government contractors. If Congress has not spoken, who decides these questions and by what standards?

\section{Mr. Martin:}

As I understand it, the final arbiter of these disputes is the Supreme Court. Even though the underlying problems are rather unsuited for judicial decision, the Court

${ }^{10} \mathrm{Cf}$. Groves, Introduction, Tax Immunities on Federal Property, 1959 Wis. L. Rev. 167. 
must act to preserve some semblance of order and fill the "gap in law making." With apologies to Judge Friendly, this is a controversy that Congress won't resolve and where the courts, to the consternation of many, seem to be filling a quasilegislative role by default. ${ }^{11}$ Perhaps they shouldn't, but they have undoubted power to act here.

Mr. Fish:

The government's basic position, as reflected in standard contract tax clauses and cost principles, is that there is no contractual duty to compensate a contractor for taxes from which he is exempt under either state or federal law. ${ }^{12}$ In many cases this exemption may be granted voluntarily by the state. In the difficult cases, however, the limitation, if any, on a positive exercise of the state tax power is found in the federal constitution. I am thinking particularly of the fourteenth amendment and the "commerce" and "supremacy" clauses. ${ }^{13}$

\section{Mr. Charles:}

In other words, my client's contractual tax position with the United States depends primarily upon whether the state and local governments have validly exercised the power to tax and whether the tax itself is both reasonable in amount and allocable to contract performance.

Mr. Fish:

Exactly. To determine the outer limits of this tax power we must piece together the many decisions of the Supreme Court, which, to some, have produced a wavering line drawn by an unsteady hand. ${ }^{14}$

\section{Mr. Martin:}

Professor Potter has made a study of these decisions. Perhaps, sir, you could shed some light on where the judicial line has been drawn and by what standards.

\section{Professor Potter:}

Thank you. Let's first provide a framework for the discussion. When a government agency needs supplies or services to accomplish a particular objective and

${ }^{11}$ See Friendly, The Gap in Law Making-Judges Who Can't and Legislators Who Won't, 63 CoLum. L. Rev. 787 ( 1963 ). The Court has undertaken the task of adjusting intergovernmental tax immunities with some trepidation. See, e.g., United States v. City of Detroit, 355 U.S. 466, 474 (1958) (a wise and flexible adjustment calls for political and economic considerations of the greatest difficulty and delicacy); McCulloch v. Maryland, I7 U.S. (4 Wheat.) 316,430 (I8I9) (a perplexing inquiry so unfit for judicial determination).

${ }^{12}$ See notes 2 and 3 supra.

${ }^{13}$ U.S. CoNsr. amend. XIV, § I: "No State shall make or enforce any law which shall abridge the privileges or immunities of citizens of the United States; nor shall any State deprive any person of life, liberty, or property, without due process of law; nor deny to any person within its jurisdiction the equal protection of the laws"; U.S. Const. art. I, $\$ 8$, cl. 3: "The Congress shall have Power ... To regulate Commerce . . . among the several States . . ."; U.S. Const. art. VI: "This Constitution, and the Laws of the United States which shall be made in Pursuance thereof . . . shall be the supreme Law of the Land; and the Judges in every State shall be bound thereby, any Thing in the Constitution or Laws of any State to the Contrary notwithstanding."

${ }^{14}$ See, e.g., United States v. Livingston, supra note 7, at I9. 
cannot obtain them from other government sources, a procurement from private business becomes necessary. After advertising or negotiation a contract is awarded, some enterprise delivers the supplies or performs the services, and the price is paid. There are two basic "givens" here. First, the government is compelled by necessity to use private contractors; and, second, the private "agency" selected is in fact performing public functions. I think it's fair to say that there is an increasing mutual dependence of the contracting community and the United States upon each other. And, certainly, the private contractor is an indispensable element in national defense. The contractual relationship, then, involves a curious fusion of private and public interests.

The performance of this government contract will, of course, take place within the tax jurisdiction of a particular state or local government. This state will probably have the typical "business" taxes, such as franchise, income, and sales and use, and the standard ad valorem real and tangible personal property taxes. ${ }^{15}$ The contractor will be using real and personal property owned by himself and the United States and engaging in the purchase of raw materials or components for performance. In short, as an active business operation the government contractor is a prime subject for all varieties of state and local taxation. Given the complexity and variation in government needs and the ingenuity of state legislatures and tax assessors, the available subjects for taxation are virtually unlimited.

Mr. Fish:

But the power of a state to tax government contractors is limited by more than ingenuity. Doesn't the Constitution impose some rather substantial limitations? What about the famous statement that the "power to tax is the power to destroy?"

\section{Mr. Martin:}

I believe Justice Marshall said "the power to tax involves the power to destroy."10

\section{Professor Potter:}

I agree. Once you have analyzed the facts and examined state law, it may become clear that without resort to the federal constitution the contractor is exempt from taxation. ${ }^{17}$ This is an exemption derived with the consent of the state or, perhaps, with the assistance of a state court interpreting its own statutes, regulations or constitution. ${ }^{18}$

\footnotetext{
${ }^{10}$ For an illuminating discussion of the growth and current importance of the so-called "business" tax, see Jerome R. Helierstein, State and local Taxation, Cases and Materials pt. i, c. i (2d ed. rg6r).

${ }^{16} \mathrm{McCulloch}$ v. Maryland, supra note II, at $43 \mathrm{I}$.

${ }^{1 \tau}$ Any tax immunity obtained by a private business concern from a contractual relationship with the United States is derivative. James v. Dravo Contracting Co., 302 U.S. 134, r57 (I937). Since the constitutional immunities of the United States are involved, a closer supervision and control over any litigation between the contractor and the state is exercised by the government. See Worf, op. cit. supra note 3 , at $4 \mathrm{r}-43$.

${ }^{18}$ According to Karl E. Wolf, as of July $\mathrm{I}$, 1962 the following types of voluntary legislative exemptions from state sales taxation were available to the United States and its contractors: 1 . No sales
} 
Mr. Martin:

In other words, these cases do not really test the ultimate power of the states to tax government contractors. They simply represent a voluntary exercise of restraint, probably motivated by a host of economic and political realities within the state itself.

Mr. Charles:

Which is simply another way of saying that if the state and local governments really wanted to, they could end the problem by generous exemptions.

Mr. Fish:

A pious hope. We all know why this discussion has any importance at all. The states will probably not abstain. With this in mind I am interested in what limitations the federal constitution has imposed upon the exercised power. If there is no limitation imposed by the state constitution and the legislature has, in a well drafted statute, actually subjected certain business transactions or property of government contractors to taxation, where do we draw the line?

\section{Professor Potter:}

We could start with the "commerce" clause, but I'm afraid this will not afford too much protection. While a government contractor may be engaged in interstate commerce, he usually has sufficient contacts with the state to justify the typical business-type taxes under both the "commerce" clause and the "due process" clause of the fourteenth amendment. ${ }^{10}$ Very rarely if ever is the government contractor engaged exclusively in interstate commerce. His real and personal property is relatively fixed and his business operations have substantial "local incidents." 20 The contractor and the government might, of course, arrange a sale to occur outside the $\operatorname{tax}$ jurisdiction and obtain some protection. ${ }^{21}$ But this is often more costly than the tax itself and still leaves the compensating use tax loophole unplugged. To the extent, then, that a government contractor is "Mr. Interstate Commerce" he may have to pay his way unless a "multiple" tax burden can be found. ${ }^{22}$

tax of any type ( $\mathrm{r}_{3}$ states); 2. Specific statutory exemption provided for sales of property to the government (23 states); 3. Sales by third persons of materials, equipment and tools to manufacturers performing under government cost-plus-fixed-fee contracts (2 states); 4 . Sales by third persons to manufacturers of materials to be consumed in production of items sold to the United States ( 77 states); 5. Sales by third persons to manufacturers of material to be incorporated into items sold to the United States (35 states). There are, however, relatively few voluntary exemptions from the use taxes in force in 37 states available to the contractor using private or government property in performance. See WoLf, op. cit. stipra note 3 , at $46-49$.

${ }^{10}$ See Northwestern States Portland Cement Co. v. Minnesota, 358 U.S. 450 (I959).

${ }^{20}$ See Indiana Dep't of State Revenue v. Bendix Aviation Corp., 237 Ind. 98, I43 N.E.2d 9I (I957), appeal dismissed, 355 U.S. 607 (1958).

${ }^{a 1}$ Compare McLeod v. Dilworth, 322 U.S. 327 (r944) (sales tax) with General Trading Co. v. State Tax Comm'n, 322 U.S. 335 (I944) (use tax). See Spector Motor Service v. O'Connor, 340 U.S. 602 (r95r) (state has no power to tax federal privilege enjoyed by private business to carry on exclusively interstate activities).

${ }^{29}$ An otherwise valid tax on a business engaged in interstate commerce may still be unconstitutional 
The "commerce" clause seems to offer the most potent protection against discriminatory taxes. In a recent Supreme Court decision, Louisiana subjected the use within the state of goods purchased outside the state to a tax measured by two per cent of the cost of manufacture. The petitioner, a foreign corporation, manufactured goods in another state and shipped them to Louisiana for use in his business there. When tax day rolled around, he discovered that while his tax was measured by both the cost of materials and manufacturing overhead, the tax on goods both manufactured and used in Louisiana was measured by only the cost of materials. As a result the petitioner had a substantially heavier tax burden and convinced the Supreme Court that the tax was an unconstitutional discrimination against interstate commerce. While admitting the possibility of "adequate justification" for the difference in treatment, the Court concluded that the tax, in practical effect and operation, imposed a substantial burden on commerce: "equal treatment for in-state and out-of-state taxpayers similarly situated is the condition precedent for a valid use tax on goods imported from out of state."23

Now, the important feature of the case for our purposes is this. The federal interest in free, unburdened access to interstate commerce could be asserted by the taxpayer on his own behalf. Further, that interest outweighed the states' purposes in attempting to foster local business. If the taxpayer were also a government contractor, the United States could avail itself under the contract of the defense. The contractor would be exempt from state taxation but the protection would flow from the "commerce" clause rather than sovereign immunity.

\section{Mr. Fish:}

Accepting this as true, since the state is directing the discrimination at the out-ofstate business concern rather than the private business concern with government contracts, the protection is something less than adequate. As Professor Potter has suggested, government contractors will seldom be in that position. ${ }^{24}$

\section{Mr. Charles:}

While on the subject, what about the "equal protection" clause of the fourteenth amendment? Hasn't this been interpreted to protect "persons" from discriminatory taxes imposed by state and local governments?

if there is a substantial risk that the same transaction will be taxed again in another state. Cf. Northwestern States Portland Cement Co. v. Minnesota, supra note I9 at $462-63$. In effect, interstatc commerce is subjected to a risk of multiple taxation not borne by local commerce. For a discussion of the current state of this notion and a citation of authorities, see Hellerstein, op. cit. supra note I5, at I6 $x-65$.

${ }^{23}$ Halliburton Oil Well Cementing Co. v. Reily, 373 U.S. 64 (rg63). The Court also reasoned that the tax scheme tended either to induce business to settle in Louisiana or to stay out. The inducement was unconstitutional because it forced the taxpayer to become a resident in order to competc. By neutralizing the advantages of the taxpayer's domicile, Louisiana invited a "multiplication of preferential trade areas destructive of the very purpose of the commerce clause." Id. at 72-73 (quoting Dean Milk Co. v. Madison, 340 U.S. 349,356 (r95I)).

${ }^{24}$ For a recent decision rejecting the "commerce" clause as a defense to state taxation of a government contractor, see American Oil Co. v. Neill, 383 P.2d 350 (Idaho I963). 
Professor Potter:

Indeed it has, but slightly different considerations are involved there. Let's take the facts of a fairly recent Supreme Court decision, Allied Stores Ind. $v$. Bowers. ${ }^{25}$ The state of Ohio subjected to taxation "all personal property located and used in business" in the state. "Used in business" was defined to include personal property "when stored or kept on hand as material, parts, products, or merchandise." However, the statute provided that the "merchandise" of nonresidents of the state was not "used in business in this state if held in a storage warehouse for storage only." This exemption was upheld under the "equal protection" clause over the objection of a resident taxpayer whose merchandise in storage had been taxed. Since the probable purpose of the exemption was to induce nonresident business into Ohio, the apparent inequality of treatment was founded upon a reasonable distinction, or difference in state policy. The exemption furthered some legitimate policy of the state. Let me read from this revealing opinion.

The states have a very wide discretion in the laying of their taxes. When dealing with their proper domestic concerns, and not trenching upon the prerogatives of the national government or violating the guaranties of the federal constitution, the states have the attribute of sovereign powers in devising their fiscal systems to ensure revenue and foster their local interests. Of course, the states, in the exercise of their taxing power, are subject to the requirements of the equal protection clause of the fourteenth amendment. But that clause imposes no iron rule of equality, prohibiting the flexibility and variety that are appropriate to reasonable schemes of state taxation.... [However] the state must proceed upon a rational basis and may not resort to a classification that is palpably arbitrary. The rule often has been stated to be that the classification "must rest upon some ground of difference having a fair and substantial relation to the object of the legislation." ... If the selection or classification is neither capricious nor arbitrary, and rests upon some reasonable consideration of difference or policy, there is no denial of the equal protection of the law. ... [I]t has long been settled that a classification, though discriminatory, is not arbitrary nor violative of the equal protection clause of the fourteenth amendment if any state of facts reasonably can be conceived that would sustain it. ${ }^{20}$

\section{Mr. Sampson:}

I can see that the "commerce" clause is not involved here since the exemption favors the nonresident. It induces him by the prospect of favorable tax treatment but at the same time does not compel him to come at the risk of being placed at a competitive disadvantage with residents of the state. ${ }^{27}$

${ }^{25} 358$ U.S. 522 (1959).

20 Id. at 526-27.

${ }^{27}$ For recent state court decicions justifying under "equal protection" certain tax exemptions designed to attract industry, see Armstrong v. State, 6I Wash. 2d II6, 377 P.2d 409 (x962); In re Borough of Aliquippa, 405 Pa. 42I, I75 A.2d 856 (Ig6I); Spatt v. City of New York, I4 A.D.2d 30, 218 N.Y.S.2d 409 (Ig6r). Cf. Central R.R. v. Pennsylvania, 370 U.S. 607 (I962). But see F. S. Royster Guano Co. v. Virginia, 253 U.S. 4r2 (I920) (state not justified in taxing income of domiciled corporation earned within and without state and at same time exempting domiciled corporation's income earned outside of state when that corporation does no business within state). 


\section{Mr. Martin:}

In other words, the reason for the exemption fostered local interests and did not clash with "the guaranties of the federal constitution" other than the restriction of "equal protection." It would seem that the range of potential state justifications for different tax classifications is much broader than simply inducing non-resident business into the state. ${ }^{28}$

\section{Professor Potter:}

Perhaps, but before we get too enthusiastic a word of caution is in order. Suppose our taxpayer is a government contractor and he pays more tax than the exempt non-resident storer. The quotation from Allied Stores suggests that even if a state justification satisfies "equal protection" it still may trench "on the prerogatives of the national government." It's one thing to balance an individual taxpayer's interest in equal tax treatment against legitimate interests of the state when no federal interests are involved. Allied Stores tips that balance in favor of the state. But we have seen that the "commerce" clause, in the interest of a broader federal policy, can tip the scale back in favor of the individual taxpayer even though the state seeks to foster internal economic situations. Now if our taxpayer is a government ...

\section{Mr. Charles:}

Excuse me. I hate to interrupt, but aren't we drifting a bit from the theme. The net effect of this discussion seems to be that while there are several defenses that a contractor may assert in his own right-without depending upon the government's sovereign immunity-as a practical matter they are not often available. None of them offer much consistent protection to either the contractor or the United States. So I get a definite feeling that unless the state has voluntarily exempted the contractor, he must pay and the United States must reimburse. Doesn't this support Professor Potter's earlier statement that the subjects available for taxation are virtually unlimited? And if this is true, is this problem really unique? I mean, if the states in most cases have power to tax the business activities of government contractors and the question is simply whether the legislature will or will not exercise it, there's not much left to discuss.

\section{Mr. Fish:}

Whether you appreciate it or not-and you should-there is a clear federal interest involved here that we have not fully discussed. It all goes back to our conclusion that the practical operation of state and local taxation falls on the federal pocket-book and burdens the government contracting process. Why shouldn't the doctrine of "sovereign" immunity protect the United States here?

\section{Mr. Martin:}

Professor, are you ready to talk about "sovereign" immunity now?

${ }^{28}$ See, e.g., Stebbins v. Riley, 268 U.S. I2I (I925); Heisler v. Thomas Colliery Co., 26o U.S. 245 (1922); Wiramal Corp. v. Director of Div. Taxation, 36 N.J. 20r, I75 A.2d 63r (196r). 
Professor Potter:

I suppose so, but I'm not so sure it will help much. Let's look at first things first. A basic and unchallenged tenet of our federal system is that the state and local governments have no power directly to tax the United States, its agents or instrumentalities. This immunity has been implied by the Court from the "supremacy" clause, the undoubted power of Congress to take necessary and proper steps to protect vital federal projects, and the nature of our federal system. ${ }^{29}$ This "invisible shield" means absolute immunity. It does not require proof that the tax has substantially obstructed or burdened the accomplishment of federal functions. Mr. Justice Frankfurter has expressed this exclusive idea quite well $:^{30}$

The distinction embodies a considered judgment as to the minimum safeguard necessary for the national government to carry on its essential functions without hindrance from the exercise of power by another sovereign within the same territory. That in a particular case there may in fact be no conflict in the exercise of the two governmental powers is not to the point. It is in avoiding the potentialities of friction and furthering the smooth operation of complicated governmental machinery that the constitutional doctrine of immunity finds its explanation and justification.

In view of this, the Supreme Court has invalidated a local, ad valorem property tax levied on property owned by the United States ${ }^{31}$ and a state tax imposed on the privilege of the United States to purchase goods for consumption or to use goods purchased. $^{32}$ In these cases, the infirmity exists because property owned and privi-

${ }^{20}$ See, e.g., West v. Oklahoma Tax Comm'n, 334 U.S. 717, 723 (I947) (federal tax immunity implied from supremacy clause and necessity that government act in freedom from the interference and embarrassment that state taxation might create); Knowlton v. Moore, I78 U.S. 4I, 60 (I899) (United States not a proper subject of taxation since power might be exercised "oppressively, and in derogation of dignity, subversive of powers and repugnant to paramount authority"); McCulloch v. Maryland, I7

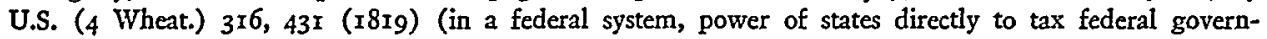
ment "involves" the power to destroy). In McCulloch v. Maryland, suspra, the Court invalidated a state tax which both discriminated against and fell directly upon the operations of a federal bank. Mrr. Justice Stone later stated the reason for the decision:

"Congress, having power to establish a bank by laws which enacted under the Constitution are supreme, also had power to protect the bank by striking down the state action impeding its operations; and it was thought that the state tax in question was so inconsistent with Congress' constitutional action in establishing the bank as to compel the conclusion that Congress intended to forbid application of the tax to the federal bank notes." Helvering v. Gerhardt, 304 U.S. 405, 4 II (1938).

${ }^{30}$ City of Detroit v. Murray Corp., 355 U.S. 495,504 (I958).

32 United States v. Allegheny County, 322 U.S. I74 (I944). Accord: Rohr Corp. v. San Diego County, 362 U.S. 628 ( 1960 ); United States v. County of Lawrence, 280 F.2d 462 (3d Cir. 1960), aff'd, 364 U.S. 628 (Ig6r).

${ }^{32}$ Kern-Limerick v. Scurlock, 347 U.S. Iro (I954) (legal incidence of state sales tax falls on contractor designated as a purchasing agent of the United States). See Standard Oil Co. v. Johnson, 316 U.S. $48 \mathrm{I}$ (1942) (post exchange is federal instrumentality and thus immune from state taxation). Cf. Curry v. United States, 3 I $_{4}$ U.S. I4 (rg4I) (implicit that United States as "user" of goods immune from state tax on use of goods).

Determining the "subject," "measure," and "legal incidence" of state taxation is primarily a question of state law. A variety of factors may color this interpretation. See WoLf, op. cit. supra note 3, at 20. The legal effect of a state or local tax which is apparently levied on the United States or its contractors is, however, ultimately a question of federal law and the state's characterization and interpretation are reviewable by the Court. United States v. Allegheny County, supra note 3r. In determining whether 
leges exercised by the United States are subjected to taxation. In addition, the United States as owner or user is also legally responsible for payment of the tax-i.e., the legal incidence of taxation is on the government.

The crucial question here, as I see it, is the extent to which a private business enterprise-an "independent" contractor-whose privileges and property are freely taxable, derives additional tax immunity by entering into a contract with the United States. Does he obtain total immunity, partial immunity, or none at all? How does the award of a contract restrict the power of state and local governments to tax?

\section{Mr. Sampson:}

The simple answer is: Not very much at all when normal procurement practices are followed. I admit that a complete answer would require more detail but it seems clear that a private business concern derives virtually no immunity from the contract itself.

\section{Mr. Martin:}

Can you be a bit more specific. We are suffering from over-generality.

\section{Mr. Sampson:}

Well, let's go back to the professor's basic illustration of a private contractor supplying goods or services to the United States. Despite the obvious public function being performed, the Court has consistently held that he is neither an agent nor instrumentality of the United States for tax purposes. His ownership of property and his exercise of privileges are still taxable by the state in the absence of anything more. Thus, if the state places the legal incidence of a sales tax on the purchaser for consumption, the sale of components by a third person to the government contractor will still be taxable. ${ }^{33}$ The contractor's use of those components or others involved in the manufacturing process might also be taxable. ${ }^{34}$ And certainly real and personal property owned by the contractor and involved in contract performance will still be taxable. ${ }^{35}$ From my reading of the cases, unless the government tries in its contract clauses to make the contractor a "purchasing agent" or to vest title to components quickly in the United States, the mere award of the government contract does not and should not disturb the revenue balance. ${ }^{38}$

\section{Mr. Charles:}

In states where the legal incidence of the sales tax is placed on the purchaser, won't a contract for sale between a private business concern which is selling and the

the tax is actually laid on the United States or its property the Court "goes beyond the bare face of the taxing statute to consider all relevant circumstances." United States v. City of Detroit, 355 U.S. 466 , 469 (r958).

ss Alabama v. King \& Boozer, 3 I $_{4}$ U.S. I (r94I).

${ }^{84}$ Curry v. United States, 3r4 U.S. I4 (I94I). Accord: United States v. Boyd, supra note 7. If the contractor is using government-owned property and the tax subject is "use incident to ownership" the tax is invalid. E.g., Avco Mfg. Corp. v. Connelly, I45 Conn. I6I, I40 A.2d 479 (1958); Tawes v. Aerial Products, Inc., 210 Md. 627, r24 A.2d 805 (r956).

${ }^{85}$ Gromer v. Standard Dredging Co., 224 U.S. 362 (19x2).

${ }^{38}$ See supra note 7 . 
United States which is buying be exempt? This is what I've been advising my clients, at least.

\section{Professor Potter:}

You are correct, Mr. Charles. In defining the outer limits of tax power, the Court first determines what subject and which taxpayer the state legislature has actually taxed. In your situation, if the privilege of purchasing for consumption is the subject and the purchaser is liable to the state for non-payment, the tax is unconstitutional. On the other hand, if the subject is the privilege of selling at retail and the legal incidence is placed on the seller, the tax is constitutional. .7 $^{37}$ Actually, the determination of what subject and which taxpayer decides the scope of sovereign tax immunity. While this is essentially a question of state law, it is clearly mixed with a vital federal question and is subject to federal judicial review. And I agree with Mr. Sampson that essential revenue relationships are not altered substantially by the award of government contracts.

\section{Mr. Fish:}

How sterile this is. Regardless of how the questions "what subject and which taxpayer" are answered, the essential economic and administrative burdens on the federal contracting process are the same. The government has to pay whether the legal incidence falls on the seller or the buyer. Shouldn't the constitutionality of taxes in this area depend upon an assessment of actual burdens? As I understand this discussion, the test has nothing to do with practical operation. If the legislature carefully drafts the tax to reach the contractor's private interests and places the legal incidence on him the United States cannot complain. At least, the Court will not give relief. Yet in your illustrations and in our earlier discussion we recognized that the actual burdens on the United States are the same. This is arid conceptualism at its worst.

\section{Mr. Sampson:}

My friend can see only one side of the problem. He, too, wants all or nothing and that's not very realistic either. I think we must assume that the state has legitimate interests here which would be seriously impaired if every government contractor were immune from taxation. And this would be particularly objectionable if it were immunity conferred by the Court rather than Congress. But to protect state revenue interests the Court has consistently utilized a practical construction of the implied immunity idea. Recognizing that the operation of two governments within the same sphere invariably has some effect each upon the other, the Court has sought a line that permits both to operate with minimum interference from the other. The legal incidence test is that line. If the difference between taxing the contractor's and the government's interests when in either case the practical operation is the same appears to be no distinction at all, it is because close distinctions are

${ }^{37}$ United States v. Dep't of Revenue, 202 F. Supp. 757 (N.D. III. I962), affd, 37I U.S. 21 (1962). 
necessary to maintain the necessary freedom of both governments from undue limitations or burdens on their activities. This is a calculated probability test based on the assumption that taxation of the agency, i.e., a private business concern, is not necessarily taxation of the means. ${ }^{38}$

\section{Professor Potter:}

Professor Thomas Reed Powell recognized almost twenty years ago that the test of constitutionality in this area depended upon "who is hit rather than who is hurt." 39 While this is not the only way of testing the outer limits of power in a federal system, it has the virtue of being relatively simple to administer and providing a fair amount of certainty. The Court does not weigh in each case competing state and federal interests or examine actual burdens. The Court has recognized that a test based upon an assessment of economic burden would be "illusory and incapable of consistent application." ${ }^{\prime 0}$ And finally, there is an express recognition that the United States must also bear some of the burdens in a federal system. Even interstate commerce must pay its way. Nondiscriminatory economic burdens are a "necessary incident" to a concurrent operation of both state and federal governments. ${ }^{41}$ It is my opinion that the Court has tacitly recognized that while these questions are unfit for judicial determination a resolution of the controversy is essential to ordered processes. Our conceptual test is the necessary result.

\section{Mr.Fish:}

That sounds very nice and perhaps it has validity in limited, stable situations. The fact is, however, that this test-this all or nothing approach-gives the states

${ }^{38}$ James v. Dravo Contracting Co., 302 U.S. 134, 150 (1937). See also Metcalf \& Eddy v. Mitchell, 269 U.S. 5I4, 523-24 (1926), where Mr. Justice Stone, in validating a federal income tax imposed upon independent contractors of a state, stated:

"In a broad sense, the taxing power of either government, even when exercised in a manner admittedly necessary and proper, unavoidably has some effect on the other .... Taxation by cither -. a affects in some measure the cost of operation of the other. But neither government may destroy the other nor curtail in any substantial manner the exercise of its powers. Hence the limitation upon the taxing power of each, so far as it affects the other, must receive a practical construction which permits both to function with the minimum of interference each with the other; and that limitation cannot be so varied or extended as seriously to impair cither the taxing power of the government imposing the tax ... or the appropriate exercise of the functions of the government affected by it."

${ }^{30}$ Powell, The Remnant of Intergovernmental Tax Immunities, 58 HaRv. L. REv. 757, 787 (I945). See Miller, State Power Over the Federal Contractor: A Problem in Federalism, II VAND. L. REv. 175, I83 (x957). Mr. Justice Harlan, dissenting in City of Detroit v. Murray Corp., 355 U.S. 495, 505-510 (r958) stated that while the "legal incidence" or "privilege" test involved a "high degree of artificiality, the line at least was visible and since the government had relied upon it in drafting contract clauses further adjustment should be left to Congress.

${ }^{10}$ United States v. City of Detroit, supra note 32, at 473 n.4.

"Alabama v. King \& Boozer, 3I4 U.S. I, 8 (I94I): "So far as such a nondiscriminatory state tax upon the contractor enters into the cost of materials to the Government, that is but a normal incident of the organization within the same territory of two independent taxing sovercignties." Accord: Detroit v. Murray Corporation of America, 355 U.S. 489, 495 (I958). The Court has recently affirmed the "legal incidence" test where the "practical operation" of a nondiscriminatory sales tax fell admittedly on the United States but the legal incidence was placed on the seller. United States v. Dcp't of Revenue, supra note 37 . 
power to exploit the unique and unparalleled requirements and techniques of defense contracting. All the state legislatures need to do is isolate a private interest involved in a government contract, subject that to taxation, and place the legal incidence on the contractor. The tax is constitutional and since the United States cannot, as a practical matter, refuse to reimburse the contractor the real burden of taxation is passed on to the public treasury. Isn't it perfectly clear now that the only real limitations upon the state tax power here are the volume and complexity of government contractors and the lack of ingenuity of state legislatures?

\section{Mr. Martin:}

Mr. Fish, are you referring to the Michigan Tax Cases?

\section{Mr. Fish:}

Essentially yes, but the point goes deeper than that. If the states really wished to maximize revenue at the expense of the United States they could revamp a large variety of taxes to avoid the doctrine of implied immunity. For example, all sales tax legislation could put the legal incidence on the vendor. And the Michigan Tax Cases are beautiful examples of new taxes seemingly devised to exploit the possession by private contractors of government-owned real and personal property.

\section{Mr. Charles:}

As I understand those cases, ${ }^{42}$ a state may tax the contractor's "possessory" interest in government-owned real or personal property in his possession by lease or license if that property is used in a business conducted for profit and the tax debt is the personal obligation of the contractor. It doesn't make any difference whether the property is used to perform a government contract or not. And the tax may be measured by the full value of the property, not just the value of the contractor's possessory interest. These are more "privilege" than property taxes and ignore actual ownership in their approach.

Mr. Fish:

Don't you see my point now. There are very good reasons for the government to furnish real and personal property to its contractors. It facilitates and reduces the cost of contract performance. ${ }^{43}$ Yet the states are now given a tremendous power to single out the contractor's "possessory interest" in the property and tax it just as if the government still had possession. What subterfuge. The potential burden on the public treasury is staggering and there is no real evidence that immunity

\footnotetext{
${ }^{42}$ United States v. City of Detroit, 355 U.S. 466 (r958) (lease of realty to private commercial concern for non-government use); United States v. Township of Muskegon, 355 U.S. 484 (I958) (license of realty to contractor for use in performing government supply contract); Detroit v. Murray Corp., 355 U.S. 489 ( 1958 ) (personal property in possession of subcontractor to which government obtained title by making progress payments). These cases are well discussed in Department of thre ARMx, ProcureMrNT LAw 306-3I2 (I96x); Whelan, supra note 7; Van Cleve, supra note 4, at I97-204; Keesling, Property Taxation of Leases and Other Limited Interests, 47 CaLIF. L. REv. 470 (I959); Comment, 36 U. DET. L.J. 323 (1959).

${ }^{43}$ See Department of the Army, Procurement Law 283-86 (rg6r).
} 
here would create state financial hardships. Without government contracts the property would never be in private hands and of course would be immune from taxation.

\section{Professor Potter:}

You sound like a prophet of doom. Those cases were decided in I958; yet there has not been an overwhelming surge to get on the bandwagon. At the present time only a few states specifically authorize the taxation of private interests in federal real estate leased to individuals and business concerns. Only three states have "possessory" interest type taxes like Michigan and at least eighteen states since I958 have refused to adopt this tax form. ${ }^{44}$ To top this off, both state and federal courts have consistently invalidated efforts to tax possessory interets under the old ad valorem property taxes. ${ }^{45}$ Even the Michigan Supreme Court rejected the Supreme Court's interpretation of its own statute. ${ }^{46}$ The upshot of this is that if the state desires to tax "possessory" interests it must clearly say so in properly drafted legislation. It seems to be unconstitutional here to cram the new wine in the old bottle. As a result we can conclude, in the year 1964 , that the theoretical power of the states to tax private interests in the government contract process has not been fully exploited.

\section{Mr. Martin:}

How can this be so if the states have increased revenue needs yet fewer subjects of taxation. Doesn't the mere fact that the states have not fully exercised their constitutional power to tax indicate that complaints about "fiscal hardships" caused by federal tax immunity are a lot of nonsense? What other explanations are there for voluntarily passing up a whole new source of revenue?

\section{Mr. Charles:}

No, there's more to it than that. Take the relative competitive position of a contractor doing business in Michigan and a contractor doing business in Indiana. If

"See Wolf, op. cit. supra note 3 at 8-1o.

15 United States v. Allegheny County, 322 U.S. I74 (I944); Martin Co. v. State Tax Comm'r, 225 Md. 404, I7I A.2d 479 (I96I); General Dynamics Corp. v. County of Los Angeles, $5 \mathrm{I}$ Cal. 2d 59, 330 P.2d 794 (1958). Accord: Thiokol Chemical Corp. v. Morris County, 76 N.J. Super. 232, 184 A.2d 75 (Super. Ct. 1962) (licensee of tax exempt federal real estate exempt from statute permitting taxation of leasehold interests in tax exempt property).

${ }^{4}$ Continental Motors Corp. v. Township of Muskegon, 365 Mich. I9r, 112 N.W.2d 429 (196r). In the Detroit and Muskegon cases, supra note 42 , the Michigan statute taxed otherwise tax exempt real property "made available to and used by a private individual, association or corporation in connection with a business conducted for profit ... in the same amount and to the same extent as though the lessee or user were the owner of such property." 6 Mrch. STat. AnNor. $\$ 7.7(5) \&(6)$ (Supp. 1957). To seven of the nine justices, this tax was constitutional. In the Murray case, supra note 42, the state sought to tax government-owned personal property in the possession of a private contractor under the following statute: "The owners or persons in possession of any personal property shall pay all taxes assessed thereon." To five of the nine justices, this tax was constitutional. The fact that the statute differed from the first two cases was treated as a verbal omission and an empty formalism. Justices Frankfurter and Harlan dissented in Murray, however, and argued that the statute was simply an ad valorem personal property tax and did not, in fact, tax the contractor's "privilege" of using tax exempt 
both are bidding on the same government contract and government-furnished property will be used, which will have a better chance to obtain the award? If there is real competitive disadvantage and your business is substantially with the government you would quickly consider the possibility of moving to a more favorable tax climate. A lot of states are offering inducements to new industry in the form of tax exemptions and we have seen that this is consistent with the "equal protection" clause. Maybe the states have figured that it's better in the long run to keep the government contractors than tax them out of the state.

\section{Mr. Sampson:}

Even though we have real revenue needs, it's no secret that the state legislators and tax administrators are subjected to continual pressure from all kinds of interested groups. Merchants, contractors, state and local agencies receiving other federal grants, and even officers of the executive contracting agencies themselves apply pressure to go slow in this area. The bread is buttered on many sides, including the crust, and I admit that there is a serious risk if caution is abandoned in favor of full scale taxation. Whether contractors would actually leave the "drowning ship" is doubtful, however, particularly if every state increased its taxation. The prices would be uniformly higher, but the contractor would be reimbursed and not placed in a position of competitive disadvantage. ${ }^{47}$

\section{Mr. Martin:}

Let me see if I understand this. The facts show that the Court has drawn a fairly definite line, let's call it the possessory interest or "privilege" line, beyond which the states may not go. At this time, only a handful of states have reached that line at all. The state can tax if it wants to, but to tax it must say the right thing. Since very few conventional tax statutes say the right thing, the legislature must amend the statute. And in order to pick the plum, the proposal must be subjected to the varied pressures of the legislative process. How interesting!

\section{Professor Potter:}

Look at this from another angle-the angle of judicial technique. This is an illustration of a court saying to a legislature, you can do it but you have to use the right language. But note that this is a federal court speaking to state legislatures. If you want constitutionally to tax possessory interests you must enact new statutes or amend the old to fit a prescribed mold. The Michigan Tax Cases are unusual in that the Court validated the form of the Michigan legislation. But since Michigan was one of the few states with that form the implication to the other states was

property. This argument persuaded the Michigan Supreme Court which later refused to accept the majority's interpretation in Murray of the Michigan statute.

"In addition to potential economic threats to states which exercise fully their tax power, it is interesting to note that Governor Rockefeller vetoed the proposed New York "possessory" interest tax for the reason, inter alia, that it discriminated against the United States. See Kurth, The Aftermath of the Michigan Tax Decisions: State Taxation of Federal Property and Activities Today, I3 MnITARY L. REv. I67, r69 (I96r). 
clear. Now consider this result in the context of our discussion. We are dealing with a problem which Congress has not resolved. Yet its overall implications are better suited to legislative solution rather than decision by the Court. The Court cannot give full attention to the deeper economic and political interests and certainly cannot, in a particular case, formulate a rule that will realistically resolve all the tax controversies arising in infinitely varying contexts in fifty different states. Perhaps Congress would also choke on that one. But since the Court, by default, is the final arbiter in this area, any rule is better than no rule at all. Admitting that there is a line and actually trying to establish it is far better than the inevitable chaos of uncertainty.

I can see from the facial expressions that there is some dissent on that last proposition. All right, before you jump on me let me finish this thought. Where has the Court drawn this line? At the point which forces a legislative decision in each state before the full power to tax can be exercised. In effect, the resolution of this complex problem of federalism has been left to the individual states and their peculiar economic problems. Each state must take positive action through the legislative process and this insures a chance for competing interests to be heard. While the results are decentralized and diffused, that's the nature of this problem. It may be more realistic in the long run than a unifying federal principle here.

\section{Mr. Fish:}

What you are suggesting is that while the Court's test may be conceptual, it forces realism. In order for the states to take full advantage of their potential power to tax they must go through the legislative process. But if they do and the revenue interests prevail, then the power to tax is again limited only by lack of ingenuity in ferreting out private interests for taxation. The weakness in that is that legitimate federal interests here do not receive positive and considered protection. The balance is in favor of the state tax power and the government's only protection is the hope that the power will not be exercised. Surely there should be more effective protection than persuasion and lobbying activities.

\section{Mr. Sampson:}

Come now, Mr. Fish, what about this discrimination problem. Hasn't the government used this idea as affirmative coercion? Isn't this a primary reason for the reluctance of the states to tax?

\section{Mr. Martin:}

What do you mean by that?

\section{Mr. Sampson:}

I'm talking about the Phillips Chemical ${ }^{48}$ case and the rash of litigation that it has produced. The broad and as yet undefined implications of this case seem to

${ }^{18}$ Phillips Co. v. Dumas School Dist., $36 x$ U.S. 376 (xg60). See Speidel, The Phillips Chemical Case: A New Approach to State Taxation of Federal Contractors?, 29 U. Cinc. L. Rev. 38I (1960). 
require the state as a taxing authority to treat the United States and its contractors just as well as it treats its own contractors. If the state taxes a private interest in the government contractual relationship it must also tax the same interest existing in its own contracts with private business. If it exempts its own contractors but taxes the federal contractor, the tax is unconstitutional. This doesn't make any sense to me. It seems to me that...

\section{Professor Potter:}

Just a second. Let's lay some groundwork before we start criticizing. Prior to Ig60 there was plenty of Supreme Court dictum to the effect that a state tax imposed upon a contractor's private interests must be nondiscriminatory. In fact, the crucial case of Alabama $v$. King \& Boozer stated that a "non-discriminatory" economic burden passed on to the United States did not invalidate a sales tax whose legal incidence fell on the private contractor. ${ }^{49}$ The Ig60 decision in Phillips Chemical was the first real invalidation of a state tax on government contractors for discrimination. In that case the United States leased real estate to a private party for use in the lessee's own commercial enterprise. The United States could terminate the lease if a purchaser of the land was found during the lease term. While it isn't clear from the facts, apparently the United States did not agree to reimburse the lessee for state and local taxes paid although some compensation may have been included in the lump sum rental. In any event, we had a private lessee in possession of government real estate to be used in a business conducted for profit. But it was not clear that the United States bore the economic burden and the land was not used to perform a government contract. The government, just like any other private or state lessor, was primarily concerned with rent and the federal interests were minimized.

A political subdivision of the state of Texas taxed the lessee's possessory interest in the land, using the full value of the fee as a basis for measurement. The state statute said the right thing, and under both the Michigan Tax Cases and the Military Leasing Act the tax was apparently constitutional. ${ }^{50}$ But there was more. It was clear from both statutes and state judicial decisions that lessees of land from Texas under precisely the same circumstances would pay no tax on their leasehold interest. While the state did tax its own lessees, they were generally given more favorable

${ }^{10}$ See supra note 4I. The state tax in McCulloch v. Maryland, stupra note 29, while levied directly on the United States, was also discriminatory since it reached the activities of federal but not state banks. See also, James v. Dravo Contracting Co., 302 U.S. r34, r49-50 (I937); Panhandle Oil Co. v. Knox, 277 U.S. 218, 223 (I927) (dissenting opinion of Mr. Justice Holmes); Metcalf \& Eddy v. Mitchell, 269 U.S. 514,525 (1926). Cf. Miller v. Milwaukee, 272 U.S. 7 I3 (I927) (state tax which singles out income of tax exempt federal bonds owned by corporation as that income is distributed to shareholders invalid).

${ }^{50}$ Under the Military Leasing Act, ro U.S.C. $\$ 2667(\mathrm{e})$ (x958), Congress has consented to state taxation of the lessee's interest in federal real estate. The Texas statute authorized the state and its political subdivisions to tax "any portion of (federal) lands and improvements . . . used and occupied by any . . corporation, in its private capacity, or which is being used or occupied in the conduct of any private business or enterprise." TEx. REv. STAT. $\$ 5248$ (Supp. I950). See supra note 42. 
treatment than federal lessees and in cases where the lessor state reserved a power to terminate were completely exempted. ${ }^{51}$ Now, if we can classify lessees of federal and state land as similarly situated, inequality of treatment is apparent-greater tax burdens are obviously imposed upon the federal lessee. But the real questions are whether this is an unconstitutional discrimination, and if so against whom and by what standards. Here's where the difficulty begins.

\section{Mr. Sampson:}

I see no real difficulty here. This is just like any other "equal protection" controversy. The taxpayer, a private lessee, is complaining that other private lessees are receiving more favorable tax treatment. But we have seen that if there is any reasonable grounds for the difference in treatment, the tax imposed upon the federal lessee will not violate the fourteenth amendment. Clearly, Texas was not arbitrarily showing favoritism to its own lessees. Isn't a state, as both taxing authority and lessor, justified in the interest of administrative convenience and the reduction of costs to exempt its own lessees from taxation? Surely the Constitution does not require a state to go through the useless and wasteful motion of taxation when in fact the lessee is reimbursed out of another pocket for his tax costs. This difference in treatment does not violate the fourteenth amendment since a "state of facts reasonably can be conceived that would sustain it."52

\section{Mr. Fish:}

Naturally, I disagree with Mr. Sampson. In Phillips Chemical the Court held that the state of Texas had discriminated against the "United States and those with whom it deals." After considering the various asserted justifications for the clear discrimination, ${ }^{53}$ the Chief Justice concluded that "at least when the federal govern-

\footnotetext{
${ }^{51}$ The exemption from taxation of leases terminable by the lessor (state) upon finding a purchaser
} was judicial rather than legislative. State v. Taylor \& Kelley, 72 Tex. 297, I2 S.W. 176 (1888). Other preferences given the lessee of state land were a lower measure of taxation, Trammel v. Faught, 74 Tex. 557, $x_{2}$ S.W. $3 x_{7}$ (1889), and complete exemption if the lease term was less than three ycars. TRx. REV. STAT. §7I73 (Supp. I950).

${ }^{62}$ See supra notes 25 and 26 . The strength of this argument, if any, may depend upon whether the tax exempt land is leased by the state or the political subdivision. If the subdivision is both lessor and taxing authority and actually bears the economic burden of taxing its own lessec, there is greater justification for exemption. If the state is lessor but the subdivision is the taxing authority, the rent, containing an adjustment for taxes, is paid to the state and the taxes are paid to its political subdivision. In the first case, the lessor-taxing authority is in fact putting money in one pocket and paying it out of the other. In the second case, the tax money goes into the pocket of an independent political subdivision and is paid from funds of the state. An exemption, therefore, has less justification on the grounds suggested by Mr. Sampson-i.e., administrative convenience. Other reasons must be found. See infra note 53 .

${ }^{53}$ The state of Texas, to justify exemption of its own lessees, argued that it was fostering its own interests by adopting measures which facilitated the leasing of state realty and alleviated the serious impact on local finances imposed by the presence of tax exempt realty. The Court rejected both justifications, the first for the reason that it is not permissible for a state to discriminate against the United States to foster its own interests, the second for the reason that the identity of the tax exempt lease "bears no relation to the impact on local government of otherwise identical leasing activities." 36 I U.S. at $384-85$. The Court concluded: "Likewise, it is not enough to say that the State can make up in rent what it loses in taxes from its lessees. What the State's political subdivisions lose in taxes from 
ment's interests are weighed in the balance" the differences in classification seem "too impalpable to warrant such a gross differentiation." It seems to me that while the Court acknowledged that justifications for the apparent discrimination might be possible, the decision as a practical matter foreclosed any real justification for different treatment in the classification involved. The approach is just like that taken where a state tax discriminates against interstate commerce. ${ }^{54}$ As such, the broad test for justification posed under the fourteenth amendment does not apply since the tax trenches "upon the prerogatives of the national government." It is my view that the supremacy clause provides the real constitutional basis for this result and that the state has no more power to discriminate against the United States and those with whom it deals that it has directly to tax the United States, its agents and instrumentalities. ${ }^{55}$

Mr. Martin:

Are you suggesting that the Court in Phillips Chemical did not clearly identify what part of the Constitution dictated its result? Doesn't it make quite a difference in approach whether you say fourteenth amendment or supremacy clause?

\section{Mr. Charles:}

I'd say that the answer to the first question is $y e s^{56}$ and the second question is no. The reasoning behind the Phillips Chemical result may leave something to be desired. But in every subsequent state and federal decision but one $e^{57}$ where the classification has been private parties dealing with the state or federal government and the state contractor receives more favorable treatment, the tax on the federal contractor has been invalidated. Whether the court relies on "equal protection" or

the State's lessees cannot be made up in this fashion. Other local taxpayers-including the Government's lessees-must make up the difference." 36 I U.S. at 384 .

${ }^{\circ}$ See supra note 23.

${ }^{65}$ This view finds some support in Moses Lake Homes v. Grant County, 365 U.S. 744 (xg6r). There the Court, without examining justifications, invalidated on discrimination grounds a state tax upon a private lessee's interest in federal property (Wherry Housing) where all other lessees in the state, while taxed, had their tax measured in a different and distinctly more favorable manner. It should be noted, however, that Congress in consenting to state taxation of private leasehold interests in Wherry Housing projects stipulated that the tax was not to exceed the amount of taxes or assessments imposed on similar property within the state. Sec. 408, National Housing Act of 1955, as amended, 7o Stat. rogr (1956), 42 U.S.C. \$ 1594 (1958).

"This uncertainty is clearly reflected in the arguments of counsel and the court's approach in Comptroller of Treasury v. Pittsburgh-Des Moines St. Co., 23I Md. 132, 189 A.2d I07 (1963).

${ }^{67}$ In Sproul v. Gilbert, 226 Ore. 392, 424-26, 359 P.2d 543, 558-59 (I96r), the objection was that while all lessees of federal land were taxed, some lessees of state land were not, i.e., students leasing farmland while attending state schools. The court held that there was no unconstitutional discrimination, reasoning that Phillips Chemical did not require perfect parity of treatment. The difference in treatment was justified in the assumption that the legislature did not give the same exemption to federal lessees "simply because it did not occur to the legislature that federal lands would be used for the purposes giving rise to the exemption." See also, National Bank of Hyde Park in Chicago v. Isaacs, 27 Ill. 2d 205, 188 N.E.2d 704 (1963) (tax exemption for sales to state and political subdivisions but not for sales to private banks with either state or federal charters is not discriminatory since banks are privately owned enterprises and no reduction of governmental costs would result). But see United States v. Bureau of Revenue, 217 F. Supp. 849 (D. N. Mex. 1963), discussed infra note 62. 
"supremacy," the results are the same. Clearly rejected is a justification of convenience suggested by Mr. Sampson. The inconvenience in being forced to tax your own contractors does not justify the discrimination. Nor can the purpose of stimulating state contracting prevail. The theory seems to be that if a justification for exemption to reduce governmental costs is good enough for the state it is also good enough for the federal government. ${ }^{58}$

\section{Mr. Martin:}

I take it that you believe that the Constitution absolutely prohibits the type of discrimination involved here.

\section{Mr. Charles:}

All I am saying is that the types of justifications offered so far by the states have been rejected. While these are good reasons for exemption across the board, they do not justify exemption of the state contractor but not the federal contractor. Even if we accept Mr. Sampson's contention that this is a fourteenth amendment controversy, the asserted justification is still inadequate. And remember, the states are not told that they may not tax the private interest involved. They are told that, before they tax, they must put the United States and its contractors on the same level of exemption as the state and its contractors.

\section{Mr. Sampson:}

Supplementing what Mr. Charles has said, it is now reasonably clear that if the state exempts contractors dealing with privately supported charitable and non-profit organizations but not those dealing with the United States there is no unconstitutional discrimination. ${ }^{59}$ Further, the Court in Phillips Chemical suggested that a possible justification for exempting state but not federal contractors might be a

${ }^{58}$ The net effect of recent "discrimination" decisions has been to emphasize the classification of taxpayers rather than whether "equal protection" or the "supremacy" clause is involved. The uniform conclusion has been that private contractors with the state and private contractors with the federal government are similarly situated. Therefore, an exemption given to one by the state and justified by state administrative convenience and the reduction of governmental costs must also be given to the other before the tax power may be exercised. See Comptroller of Treas. v. Pittsburgh-Des Moines St. Co., 23 I Md. 132, I89 A.2d I07 (I963); United States v. Department of Revenue, I9I F. Supp. 723 (N.D. Ill. I96I), remanded, 368 U.S. 30 ( $196 \mathrm{I}$ ) (sales tax, what is good enough for the states is good enough for the United States and its contractors); Knapp-Stiles, Inc. v. Michigan Dep't of Revenue, 370 Mich. 629, 122 N.W.2d 642 ( 1963 ) (use tax, where government's interest weighed in balance state at least required to treat government contractors as well as its own). Several decisions, however, have expressly relied on the "equal protection" clause. E.g., Thiokol Chem. Corp. v. Morris County Bd. of Taxation, 76 N.J. Super. 232, $x 84$ A.2d 75 (Super. Ct. 1962) (tax on leasehold interest, equal protection is basis for invalidation).

${ }^{60}$ United States v. Dep't of Revenue, 202 F. Supp. 757 (N.D. Ill. I962), aff'd, 37r U.S. 21 (1962); United States v. Boyd, 363 S.W.2d 193 (Tenn. I962). In supporting the Illinois exemption from taxation of retailers selling to charitable, religious, and educational institutions, Judge La Buy relied on several factors: $x$. The exemption was not of recent origin but was a continuation of an old and well-established public policy; 2. Exemption encourages charitable activities and relieves the state of the burden of furnishing those essential services; 3. The institutions benefited are non-governmental and obtain their financial resources from voluntary contributions without legal obligation or compulsion. 202 F. Supp. at 759. 
legitimate need to balance the hardship caused by other federal tax exempt property in the tax jurisdiction. ${ }^{60} \mathrm{I}$ am not prepared to swallow this absolutism suggested by Mr. Fish.

\section{Professor Potter:}

Can't we work out some rational theory here? Against whom does the practical operation of the discrimination actually fall? On the basis of our discussion here today, the answer is clearly on the United States. While the contractor is "hit" by the tax, the government for a variety of reasons is compelled to absorb the "economic burden." The contractor bears little if any of the economic burden. Further, since the government must use private contractors to implement public policies and must pay a fair profit to induce the capable, the tax in reality falls on a cooperative relationship involving both private and public interests. In view of the obvious federal interests and their importance, how can a state justify exempting its contractors and not those of the United States? If a state singles out the federal contractual relationship for tax burdens not placed on the state contractual relationship it has, in fact, directly taxed the United States. Since the United States is not a person under the fourteenth amendment, ${ }^{61}$ yet is in fact the real party in interest, you cannot explain Phillips Chemical unless you conclude that absolute immunity of a private government contractor from discriminatory taxation is an integral part of the United States' implied immunity under the supremacy clause.

\section{Mr. Sampson:}

With all due respect, Professor, I cannot swallow that. The argument does not stand up. Why is there any more need to protect this so-called "relationship" when discrimination is involved than when it is not. The ultimate economic and administrative burden to the United States is the same in both cases. Look, we have seen that the states' power to tax depends upon who and what it has taxed. If it has picked out a private interest and taxed that, there is no constitutional objection even though the economic burden is passed on and the government must, as a practical matter, absorb it. But now we conclude that an otherwise constitutional tax is invalid simply because the state has exempted another private contractor from the same tax when he is dealing with the state or its political subdivision. Why should this change the result? The status and duties of the federal contractor have not been changed, the contractual relationship and the ultimate burdens to the United States remain constant. Since the risk or lack of it to the contractor is the same in

${ }^{80} 3^{6} \mathrm{r}$ U.S. at $384-85$. For other judicial authority recognizing the actual hardship imposed upon local tax systems by the presence of federal tax exempt property, see United States v. County of Lawrence, 280 F.2d 462, 469 (3d Cir. I960), affd, 364 U.S. 628 (I96I).

${ }^{01}$ See United States v. Nebo Oil Co., 90 F. Supp. 73 (W.D. La. 1950), affd, I90 F.2d ro03 (5th Cir. 1951). In United States v. Bureau of Revenue of State of New Mexico, 291 F.2d 677 (Ioth Cir. I96r), a private contractor of the United States sought to enjoin the collection of allegedly discriminatory state taxes under 28 U.S.C. $\$ 228$ I (1958). The petition was denied on the ground that the tax discrimination was against the United States and those with whom it deals. Since the United States was the real party in interest only the United States could obtain an injunction. 
both cases he won't necessarily be discouraged from competing on government contracts simply because he is exempt from taxation in state deals. Particularly is this so in light of the greater volume and profit opportunities in federal contracting. I contend that if the realities of the contractual relationship remain constant despite more favorable treatment to state contractors, the legal result should not change simply because an exemption is not given to the federal government. The concept of discrimination as applied by the court, has an almost mystical flavor that denies rational analysis. If the federal interest here deserves protection, and I doubt it, a better method must be found. ${ }^{62}$

Mr. Fish:

But haven't the states imposed greater burdens on the federal relationship than on the state? Haven't they singled out the federal contractor for a burden not imposed on other taxpayers similarly situated?

\section{Mr. Sampson:}

Absolutely not. All the state has done is exempt its own contractors from taxation. Admittedly, the ultimate cost of the contracted for service will be less to the state than the federal government if an exemption is granted. But this will also be true if the state taxes its contractor. Suppose the cost of goods sold plus profit is $\$ 5^{\circ}$ per unit. If the state buys those goods and does not impose a sales tax on the seller, the price is obviously $\$ 50$. If a three per cent sales tax is imposed the price per unit will increase to $\$ 5 \mathrm{I} .50$. But if the state collects that $\$ 1.50$ from the seller and turns around and pays him $\$ 51.50$ for the goods hasn't the state actually paid $\$ 50$ for the goods? And if the same three per cent tax is imposed on sellers to the United States, the federal government will pay a higher price no matter what the state does. The only way that the federal cost can be reduced is for the state voluntarily to exempt sales to the United States or for a court to invalidate the sale under the Constitution.

Mr. Charles:

That's what bothers me about this set-up. Despite the discrimination cases the government never derives any real, long range advantage unless the state grants a voluntary exemption. Oh sure, taxes imposed in particular or past transactions

\footnotetext{
${ }^{62}$ For an extremely narrow and probably erroneous view of what the federal interest is in discrimination cases, see United States v. Bureau of Revenue of State of New Mexico, 2I7 F. Supp. 849 (D. N. Mex. 1963). The court ignored the fact of unequal treatment and reasoned in this manner: A private contractor with the United States does not derive immunity from state taxes which he is obligated to pay by the fact that the United States will ultimately bear the economic burden. The United States cannot urge discrimination as a defense to state taxation of the contractor until the contractor is actually reimbursed for the taxes. But even if the United States has paid the contractor, its right to complain is gained by subrogation. Therefore, since the contractor never had standing in his own right to invalidate the tax the United States derives nothing by way of subrogation. While this reasoning may have some validity if the tax is otherwise constitutional, the fact of discrimination cannot be ignored under the Phillips Chemical case, see supra note 48 . The infirmity, if any, in the New Mexico tax is that activities under state auspices are preferred for that reason alone over the same activities under federal auspices.
} 
may be avoided or recovered if in fact there is discrimination. But what about the future? Look at the mess in Illinois, for example. The Illinois Sales Tax is aimed at the retailer-the subject of taxation is his privilege of selling at retail and the legal incidence falls on him. This seller passes on the cost of taxation to the consumer unless the purchaser is subject to the state use tax. In that situation, the seller is exempt from the sales tax and then acts as agent for the state in collecting the use tax from the purchaser. In sales to the United States, the purchaser is immune from the use tax. And under our analysis, since the legal incidence of the sales tax falls on the seller, the state could constitutionally tax sales to the United States. The problem here was that the state exempted sales at retail to the state and political subdivisions but not sales to the United States. In practical effect it was just like Phillips Chemical except the type of tax differed.

The United States alleged unconstitutional discrimination and won in the federal district court. The court issued an injunction against further taxation by the state of Illinois. But while this decision was pending before the Supreme Court, the Illinois Supreme Court invalidated the state exemption and the legislature actually removed it from the statute. As a result, the Supreme Court dissolved the injunction and remanded the case to the federal district court for further argument. There the United States argued unsuccessfully that the state exemption granted to non-political, non-state supported charitable and educational institutions was unconstitutional unless also granted to the United States. The district court's ruling that there was a sufficient difference in classification and reason in policy to exempt charities was affirmed per curiam by the United States Supreme Court. ${ }^{63}$ Now, what was the result of all this litigation? Precisely nothing. The United States was exactly where it was before, paying a tax on sales to it by private sellers. All that was accomplished was forcing Illinois to repeal the exemption given to sellers to the state. The result? Illinois lost a convenient and economical exemption and the United States gained nothing for the future. While it could obtain protection in the particular controversy involved it could not compel Illinois to give an exemption.

Mr. Fish:

Yes, but Illinois did voluntarily give an exemption after the litigation was completed. ${ }^{84}$

Mr. Sampson:

The government got its exemption all right, but by the most blatant form of coercion. The harassment and publicity of all that litigation practically forced the legislative exemption.

${ }^{03}$ For a brief treatment of these developments, see Clark, The Power of the State to Tax Where the Incidence Falls Upon the Federal Government, I2 DE PAUL L. REv. 240 (1963). See also, United States v. Department of Revenue, I9I F. Supp. 723 (N.D. Ill. I96I), remanded, 368 U.S. 30 (Ig6r), 202 F. Supp. 757 (N.D. Ill. 1962), aff'd per curiam, 37 I U.S. 21 (I962); Holland Coal Co. v. Isaacs, 22 Ill. 2d 477, 176 N.E.2d 889 (196r); Il. Stat. ANN. ch. 120, $\$ 44$ I (Smith Hurd, Supp. 196r).

${ }^{\circ}$ Ill. Stat. AnN. ch. I20, $\$ 441$ (Smith Hurd, Supp. Ig63). 


\section{Professor Potter:}

But if Illinois actually won the court battle, the concession that lost the war must have been motivated by other factors. Who knows exactly why exemption was granted. Perhaps a legislative fear exists that Illinois contractors will be placed in a position of competitive disadvantage. Or perhaps the state would prefer to give exemption rather than repay unconstitutional taxes collected and already spent. Also, the discrimination litigation may have focused attention upon a situation of which the legislators were unaware.

\section{Mr. Martin:}

Professor Potter and Mr. Fish, it appears that you both still have some explaining to do. Given the Illinois situation, if the cost of goods to the state will be about the same whether it exempts sellers to the state or not, and if the most the United States can do in discrimination litigation is force the state to give up a convenient and economic exemption, of what real value is the litigation. If the state really needs the revenue it will start taxing itself again and continue to tax the United States. It seems to me that the real root problem is that the United States is the only party to any of these transactions which has to pay more or bear any real risk. The contractors are both protected and the state gains nothing by taxing itself. While the discrimination doctrine can purge inequities from the tax legislation it cannot eliminate by itself the real root problem.

\section{Professor Potter:}

Perhaps we should return to some basic notions. You recall that the implied immunity of the United States from state taxation is absolute. It does not depend upon proof that the tax actually burdens or obstructs federal functions. And it was not until 194I that the Court clearly departed from an economic burden test when the legal incidence of the tax fell on a private contractor doing business with the United States. The notion here was that some reciprocal sharing of nondiscriminatory, indirect cost burdens was a necessary incident of our federal system. Actual burdens and obstructions do not invalidate the tax under these circumstances. But it seems to me that the close distinctions we have drawn to permit both state and federal governments to operate in the same sphere with minimal interference do not permit discriminatory taxation by the state. This follows whether the purpose or motive is to exploit the government contracting relationship or simply to reduce state governmental costs.

As Mr. Justice Frankfurter has stated, the purpose of constitutional control here is to avoid potential friction and to further the smooth operation of both governments. This delicate balance is disturbed by the fact of discrimination because the risk of greater economic and administrative burdens upon the United States is increased. The fact that actual burdens in particular cases do not appear to increase is immaterial. If the state imposes greater tax burdens on government contractors than others similarly situated, the attractiveness of government contract- 
ing may be impaired. This increased risk, though difficult to assess, is in my mind a sufficient justification for the discrimination cases.

After all, the basis for any difference in treatment here lies in the nature of the entity with which the contractor deals, not the contractor himself. And since there is little if any difference when both are governments, the exemption of state contractors but not federal looks like a discrimination against the United States. Even if the reason for state exemption is reduction of government costs, there is no reason why the federal government should not have the same benefit. It seems to me that Phillips Chemical really decided that the state of Texas had failed to meet a minimal duty of reciprocal cooperation imposed by the nature of a federal system.

Mr. Martin:

And from this must we conclude that the United States rather than the contractor is the real party in interest in this controversy?

Professor Potter:

Exactly. This is no more simply a fourteenth amendment problem than is the discriminatory taxation of interstate commerce.

Mr. Sampson:

Accepting for a minute this unique thesis, do you recognize any room for the state to justify an exemption to its contractors but not to the federal government's?

Professor Potter:

None whatever. If the classification is private contractors and government, state or federal, and if the state wants to favor its own contractors by tax exemption, it must grant the same exemption to the federal government or forego the tax. It's as simple as that.

Mr. Charles:

But what about Mr. Justice Warren's suggestion in Phillips Chemical that an exemption to offset revenue hardship caused by the concentration of tax-exempt federal property might be justified. Since the federal interest in that case was minimal, wouldn't the state justification outweigh the federal prerogative? If the basic reason for exemption is to equalize a condition caused by immunity and the exemption has support in good tax administration, isn't it more realistic to balance interests here than pursue the absolutist approach?

Mr. Fish:

But isn't an interest-weighing test just as illusory and incapable of inconsistent application as the "economic burden" test? Which federal interests outweigh which state interests in each transaction ? ${ }^{65}$ Isn't it simpler to just say that if it is good enough for the state, it is good enough for the federal government. The state can tax both if it wishes; but it cannot tax one without the other.

${ }^{\text {ot }}$ See Speidel, supra note 48 , at $388-9$ r. 


\section{Mr. Charles:}

This is just great. All morning long we have been stressing the competing economic and political interests and the realities of government contracting. Then you tell me that a state cannot directly tax the United States even though there is no actual burden imposed. Next I am informed that the tax is valid if the legal incidence falls on the government contractor even though as a matter of practical operation actual burdens are assumed by the United States. Now it is asserted that if the legal incidence of a discriminatory tax is placed on the contractor the tax is unconstitutional even though the actual burdens on the United States remain about the same. Somehow the risk of future friction outweighs a legitimate state interest in reducing governmental costs but this notion is not clearly articulated. I'll have to admit some puzzlement, gentlemen.

\section{Mr. Martin:}

While I, too, am not entirely satisfied with this discussion, our time is running short and there is at least one more problem which I think should be discussed. Let's suppose that a state, in 1935, passed a sales tax which placed the legal incidence on the purchaser for consumption. Suppose further that in the next twenty-five years the United States bought increasing quantities of supplies within the state but was immune from taxation. If, in 1964 , the legislature, to increase its revenue sources, amended the legislation to place the legal incidence on the seller, would there be any constitutional objection (assuming that the tax was otherwise nondiscriminatory)? Or, to take this a step farther, suppose the federal government is the only purchaser within the state of a particular type of goods, say uranium ore. There is no commercial counterpart and the goods are used in unique defense items. Would there be any constitutional objection to a state enacting a sales tax covering these goods only and putting the legal incidence on the seller?

\section{Mr. Sampson:}

I don't see why. In both cases the state has, in properly drafted legislation, "hit" the private interest. In neither case has the state singled out the federal contract relationship for tax burdens not imposed on others. There is no suggestion that if the seller had a private commercial market for these unique goods that sales would not be taxed. How can there be discrimination if there is but one taxpayer and one purchaser in the classification?

\section{Mr. Charles:}

I think Mr. Martin is asking whether the implied tax immunity doctrine is violated any time that a state legislature amends old or enacts new taxes where the purpose or motive is to exploit the fact of government contracting within the state. 
Mr. Fish:

Exactly, and the answer to me is clear. If the state has singled out the federal contractual relationship and taxed it, the tax should be unconstitutional even though it is otherwise non-discriminatory. The test is whether the amendment or the new tax is primarily designed to exploit the fact of government contracting within the state and avoid purposely the government's implied immunity. It goes beyond both the "legal incidence" test and expands the "discrimination" test beyond the category in Phillips Chemical.

\section{Mr. Martin:}

Is there any authority for that proposition?

\section{Mr. Fish:}

Not yet, ${ }^{06}$ but I feel that this is the inevitable result of our headlong rush into the space age. There is a line beyond which I am unable to accept the close distinctions drawn by the Court-distinctions made primarily because the states do have revenue interests which need protection. But where the state has trained its tax guns on a business transaction which is uniquely federal and has little or no commercial counterpart in the state, to ignore the dictates of our federal system will be fatal. Such garble as "economic" burden and "private" interests can't obscure the fact that the state has directly taxed the United States, or, at the very least, increased the risk of substantial burdens.

\section{Mr. Sampson:}

This, of course, is ridiculous. The growth and specialization of government contracting is a natural part of a developing economy. To say that the states cannot amend their tax laws to keep pace or evolve new taxes to capitalize on innovation and progress is just plain nonsense. You are suggesting that a state cannot amend its tax laws to take full advantage of constitutional power to tax. You are suggesting that the power to pass new tax laws depends fortuitously on whether there is any other business in the state that might fit into the same subject classification of the tax.

\footnotetext{
${ }^{\circ 0}$ Mr. Justice Whittaker, dissenting in all three Michigan Tax Cases, argued for the unconstitutionality of a state tax which was directly upon the United States in substance while indirect in form, particularly where the purpose or motive for taxation was to exploit a relationship which was uniquely federal. United States v. City of Detroit, 355 U.S. 466, 477 (1958). See supra note 42. Mr. Justice Harlan, however, concurring in the Detroit and Muskegon decisions but dissenting in Murray, see supra note 46 , agreed with the "privilege" line drawn and argued that if the state has said the right thing its motive for taxation is immaterial. Motives alone do not make the tax unconstitutional. Detroit v. Murray Corp. of America, 355 U.S. 489, 507 (1958). But cf. Thiokol Chemical Corp. v. Morris County Board of Taxation, 76 N.J. Super. 232, 184 A.2d 75, 79 (Super. Ct. 1962), invalidating a discriminatory tax on lessees of the federal government, on the ground, inter alia, that the tax was intended to "circumvent" the doctrine of implied immunity "by singling out in effect lessees of the government as the tax target." Under Phillips Chemical, however, it appears that a discriminatory tax is invalid regardless of motive.
} 


\section{Mr. Martin:}

I doubt that you could convince any court that a state had no power to enact a possessory interest type simply because it was a new tax directed at the government or because within that particular state federally owned property was the only taxexempt property in the possession of private contractors. That is going a bit far. You would have to overrule the Michigan Tax Cases.

Mr. Fish:

Well, it still seems to me that there is precious little difference between the "discrimination" cases and the two examples Mr. Martin gave. Can the state intentionally single out a unique federal contractual relationship for taxation any more than it can tax sales to the federal government but exempt from taxation sales to itself. It's one thing to say that the federal interest must accommodate itself to the usual pattern of state tax laws. But beyond that, no.

\section{Mr. Martin:}

Where does this leave us? With a Congress that won't, a Court that can't or, at least, shouldn't but does, and a distinguished panel that cannot agree. That's about par for the course. Professor, do you have anything to add before we take a question or two from the floor?

\section{Professor Potter:}

It is easy to conclude from this discussion that we have a messy problem handled unrealistically. But remember that we also have fifty states with different approaches to the similar goal of taxing a varying federal contractual relationship. In the midst of these variables, the very best that the Court can do in particular cases is to draw some sort of line beyond which no state can go, or prohibit specific conduct, such as discrimination, in which no state legislature or tax administrator can indulge. Since there are important state and federal interests competing within a highly complex and evolving commercial society it is obvious that the lines cannot be drawn or the categories defined to the satisfaction of everyone. But it seems to me that the fact that the line has wavered reflects a more or less inarticulate judicial premise that the alternatives of absolute federal immunity or absolute state power to tax are unthinkable. The judicial answer, at least, lies somewhere in between.

\section{Mr. Charles:}

This is fine if every state is doing the same thing. But short of the line, wherever drawn, is a hopeless morass of diversity. If each state's approach falls short of the line but close enough to raise legitimate doubts, won't there be contingencies in all contract pricing and continuous litigation? And if the litigation from one state gets to the Supreme Court can it give a decision with validity for the other forty-nine states. This uncertainty puts real pressure on my clients who do business 
in more than one state. And doesn't it increase the risk of friction in the contracting process?

\section{Professor Potter:}

Perhaps this is the price of our federal system and a Congress that will not or cannot act. If uniformity or even consistency is impossible by judicial decision, isn't the next best solution to thrust the problem on the parties most intimately involvednamely, the states, the federal government, and the contractors. They are in the best position to work out agreements leading to tax exemptions within the realm of what is politically and economically possible. While the Court's approach is conceptual it has forced each state legislature to face up to the difficult problems presented and left ultimate solution to an informal interplay of competing interests on the local level.

\section{Mr. Martin:}

Thank you gentlemen for that stimulating discussion. We have time for one question from our patient audience. I have received that question in writing from the floor and will now read it.

In a $x 9^{6} 3$ decision, Paul v. United States, ${ }^{67}$ the Supreme Court invalidated a California minimum milk price regulation which apparently conflicted with the government's statutory and regulatory scheme designed to insure competitive bidding on contracts for supplies and services. The regulation created a price floor beneath which bidders on federal milk supply contracts could not go and which, if enforced, would impose a substantial economic loss of bargain on the United States. How can we square this case, involving regulation, with the power of the states to tax government contractors?

I wish that one hadn't been asked. On the surface, at least, the Paul case can be distinguished as involving the doctrine of pre-emption-i.e., federal law under the "supremacy" clause controls in a conflict with state law-but there is obviously more to it than that. Are there any comments from the panel?

\section{Professor Potter:}

I have trouble with pre-emption here. There is clearly a direct clash of federal and state interests, but I'm not so sure about law. The state has a legitimate concern for its milk industry and the government wishes to conserve the expenditure of appropriated funds. In regulating the milk industry by controlling the activities of individual milk retailers the state has increased the ultimate price of milk to the United States. Now isn't this about what happens in the tax cases. The state has a legitimate revenue need, it increases or adds new taxes on the activities of contractors and increases the ultimate price of supplies and services to the United States. If the interests and burdens are comparable, why should the United States receive

${ }^{07} 37 x$ U.S. 245 (1963). 
more protection from state regulation than it does from state taxation? If anything, the state's revenue interests are in greater danger. ${ }^{68}$

Mr. Sampson:

For a change, I agree with Professor Potter. The state regulates the contractor not the United States. Using the tax analogy, the legal incidence falls on a private person. And the effect of regulation has no greater impact upon the competitive bidding system than the increased cost of taxation.

\section{Mr. Fish:}

But there is an important difference that you have all overlooked. Congress, in the Armed Services Procurement Act, ${ }^{69}$ has required a process of competitive bidding wherever practical and feasible and has stated that award shall be made to the lowest responsible, responsive bidder to an invitation. The executive agencies have implemented this policy by regulations which have the force of law. ${ }^{70}$ Isn't this milk regulation squarely in conflict with federal law requiring competitive bidding? This is a direct restriction upon the implementation of an expressly stated competitive bidding policy and upon federal administrative discretion. Tax costs may be excluded by competition or careful negotiation. But if the regulation is effective, it provides a state price floor in a federal process. It's just like earlier decisions where the Court invalidated state licensing regulations which determined the responsibility standards for government contracts ${ }^{71}$ or required state approval of negotiated transportation rates between the government and private carriers. ${ }^{72}$ It's more than additional cost-the regulation directly obstructs and impairs the process itself.

\section{Professor Potter:}

Admitting that there is some restriction and that this prevents the full forces of competition to operate, is it clear from the statute and implementing regulations that Congress intended to pre-empt this type of state regulation? What do you do where there is a clear conflict of governmental interest but no clear conflict of state and federal law? If the doctrine of implied tax immunity is not absolute unless Congress has clearly spoken, why should we apply absolutism to this pre-emption idea. Surely there is room for some legitimate accommodation here. I just don't see how we can permit a general federal requirement of competitive bidding to impair the effectiveness of some rather important and specific state regulations.

${ }^{\text {es }}$ See Miller, State Power Over the Federal Contractor: A Problem in Federalism, II VAND. I. REV. I75, r90-91 (1957).

${ }^{60}$ Io U.S.C. $\$ \$ 2304$ and 2305 , as amended, 76 Stat. 528 (1962).

${ }^{70}$ Armed Services Procurement Regulation (ASPR), $\$$ II, 32 C.F.R. $\$ 2.000$ through $\$ 2.503$ (Ig63). That these regulations have the force of law, see Paul v. United States, 37x U.S. 245, 255 (x963); G. L. Christian and Associates v. United States, $3 \mathrm{I2}$ F.2d ${ }_{4} \mathrm{I} 8$ (Ct. Cl. I963), motion for rehearing and reargument denied, 320 F.2d 345 (Ct. Cl. 1963), cert. denied, 375 U.S. 954 (1963). Accord: School District 2 Fractional v. United States, 229 F.2d 68I (6th Cir. 1956).

${ }^{71}$ Leslie Miller, Inc. v. Arkansas, 352 U.S. I87 (1956).

${ }^{72}$ Public Utilities Comm'n of Calif. v. United States, 355 U.S. 534 (1958). 
Mr. Fish:

While I think the tax cases should be decided just like the Paul case, it is difficult to justify a different result and approach absent a clearer congressional directive and a more pressing federal interest. I've often wondered whether, if the Department of Defense promulgated a rule in the Armed Services Procurement Regulation that government contractors were immune from taxation or that all federal contractors were hereby constituted purchasing agents of the United States, these regulations would have the force of law and pre-empt state tax legislation. ${ }^{73}$ Suppose the justification was conservation of appropriated funds. Can it be fairly said that Congress delegated this lawmaking power to the executive agencies or, if so, whether its exercise is at all wise? It is doubtful that Congress intended or would sanction the executive departments' conferring blanket tax immunity by the stroke of a pen. ${ }^{74}$ And it is just as doubtful that Congress intended the Armed Services Procurement Act and implementing regulations to invalidate every legitimate state regulation of internal problems which conflicted with the process of competitive bidding.

Mr. Martin:

Gentlemen, I'm afraid that our time is up. We have raised a lot of interesting and controversial questions today but have seemingly failed to provide any real solutions. I trust that considerable attention will ultimately be paid to resolving these vital problems of federalism and that at some conference in the future we will be gathered to discuss a congressional solution. But until that time I doubt seriously whether the Court could realistically improve upon its approach to these difficult questions. And as moderator, I reserve the right to the last, if not the final word.

${ }^{73}$ In Kern-Limerick, Inc. v. Scurlock, 347 U.S. I ro (1953), the Court found no express prohibition in the Armed Services Procurement Act, supra note 69, on the use by the United States of private contractors as "purchasing agents." Absent an express limitation, the executive agencies had authority to draft contract clauses to conserve funds and the form of the contract could determine the question of sovereign immunity.

${ }^{74}$ Mr. Justice Douglas, dissenting in Kern-Limerick, supra note 73, argued against the wisdom of making private contractors government agents to avoid taxes. Absent express congressional authority for this practice, it is improper to permit a "government functionary to draw the constitutional line by changing a few words in a contract." 347 U.S. at I26. Subsequent to Kern-Limerick, a bill was introduced in Congress to "eliminate claims of immunity from State and local taxes based on contracts with the United States or its agencies or instrumentalities." S. 6, 85th Cong., 2d Sess. (1958). This bill passed the Senate and died in the House. Pierce, Tax Immunity Should Not Mean Tax Inequity, I959 WIS. L. REv. I73, I83-84. 